\title{
A Non-Targeted High-Resolution Mass Spectrometry study for extra virgin olive oil adulteration with soft refined oils: preliminary findings from two different laboratories
}

Daniele Cavanna ${ }^{1,2}$, Kamila Hurkova $^{3}$, Zbyněk Džuman ${ }^{3}$ Andrea Serani ${ }^{4}$, Matteo Serani $^{4}$, Chiara Dall'Asta ${ }^{2}$, Monika Tomaniova ${ }^{3}$, Jana Hajslova ${ }^{3}$, Michele Suman $^{1 *}$

${ }^{1}$ Advanced Laboratory Research, Barilla G. e R. Fratelli S.p.A., Via Mantova 166-43122 Parma (Italy)

${ }^{2}$ Department of Food and Drug, University of Parma, Parco Area delle Scienze 95/A-43124 Parma,(Italy)

${ }^{3}$ University of Chemistry and Technology, Prague, Department of Food Analysis and Nutrition, Technicka 3, 16628 Prague 6 (Czech Republic)

${ }^{4}$ COTECA Srl Consulenze Tecniche agroindustriali - 56121 Pisa (Italy)

*CORRESPONDING AUTHOR

Dr. Michele Suman, Ph.D

Barilla G. R. F.1li SpA, Food Research Labs

via Mantova 166

43122 Parma (Italy)

Phone: +39-0521- 262332

Email: michele.suman@barilla.com

\section{SUPPORTING INFORMATION}




\section{SECTION 1 - MULTIVARIATE STUDIES}

The Total lon Chromatograms in ESI + ionization of a pure EVOO sample, of mixture A and of mixture $\mathrm{H}$ are presented in the figure below.

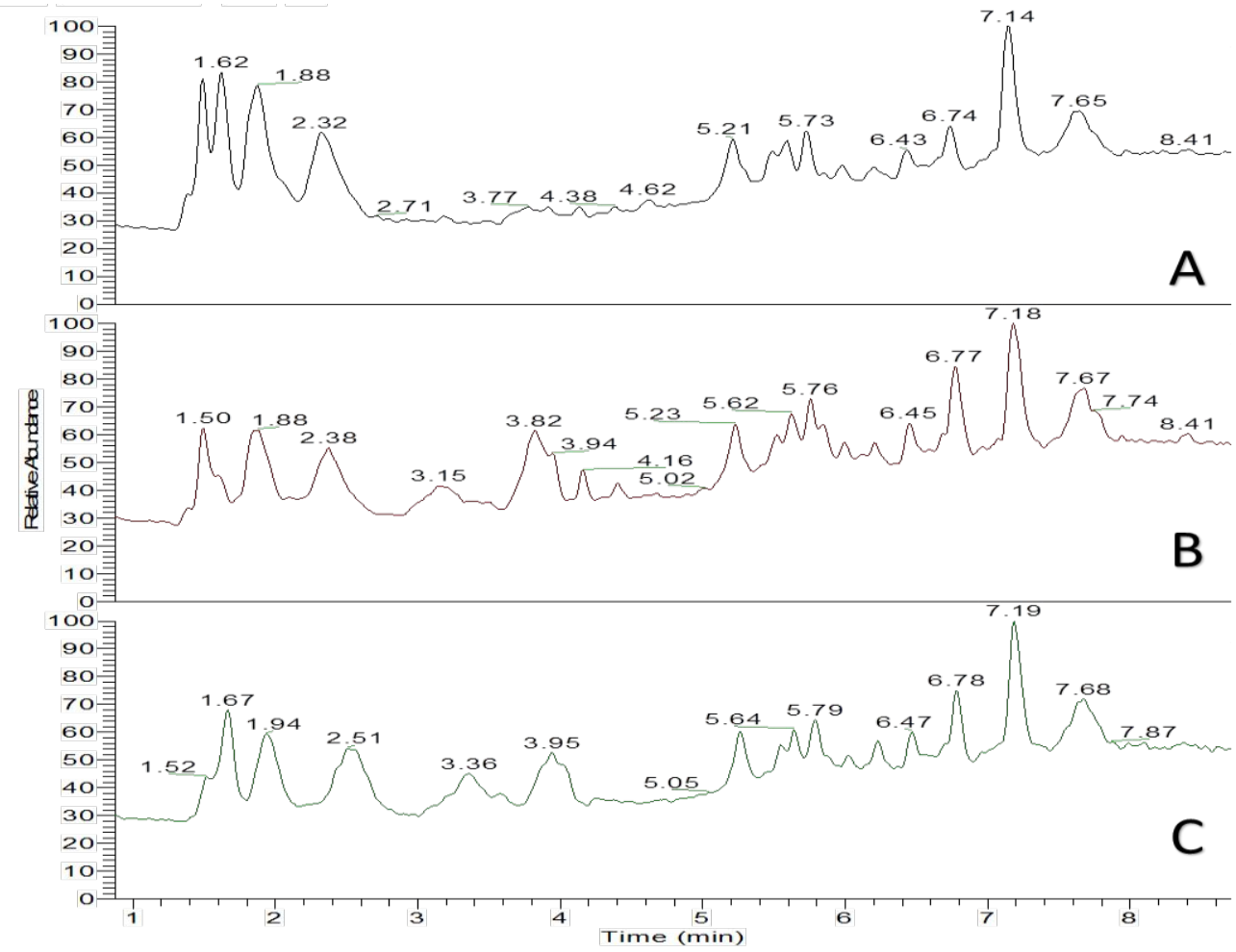

Figure S1. Total lon Chromatograms (ESI + ionization from 1 to $9 \mathrm{~min}$ ) of (A) pure EVOO sample; (B) mixture A; (C) mixture $\mathrm{H}$ 
The PCA scores plot of the results obtained for both the ionization modes including the QC samples are presented in figures S2 and S3.
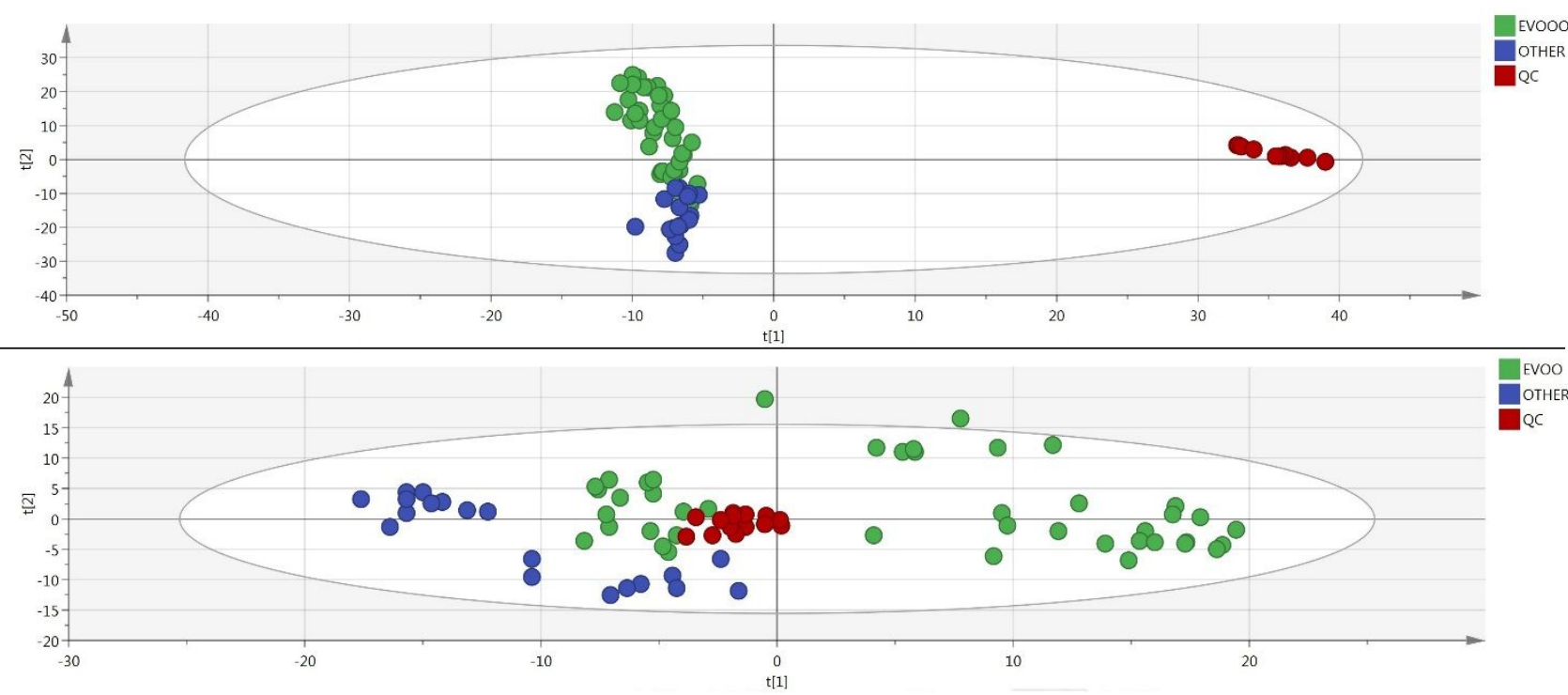

Figure S2. ESI + PCA Scores plots of the samples including QCs (X axis: PC1, Y axis: PC2). A: Laboratory \#1; number of PCs: 9; explained variance of of each PC: PC1 33.7\%, PC2 22.0\%, PC3 8.7\%, PC4 5.8\%, PC5 4.7\%, PC6 4.1\%, PC7 2.6\%, PC8 2.0\%, PC9 1.5\%, B: Laboratory \#2; number of PCs: 10; explained variance of each PC: PC1 18.8\%, PC2 7.1\%, PC3 5.9\%, PC4 4.9\%, PC5 3.8\%, PC6 3.4\%, PC7 3.0\%, PC8 2.7\%, PC9 2.5\%, PC10 2.1\%. Green dots: "EVOO" samples; blue dots: "OTHER" samples; red dots. "QC" samples.

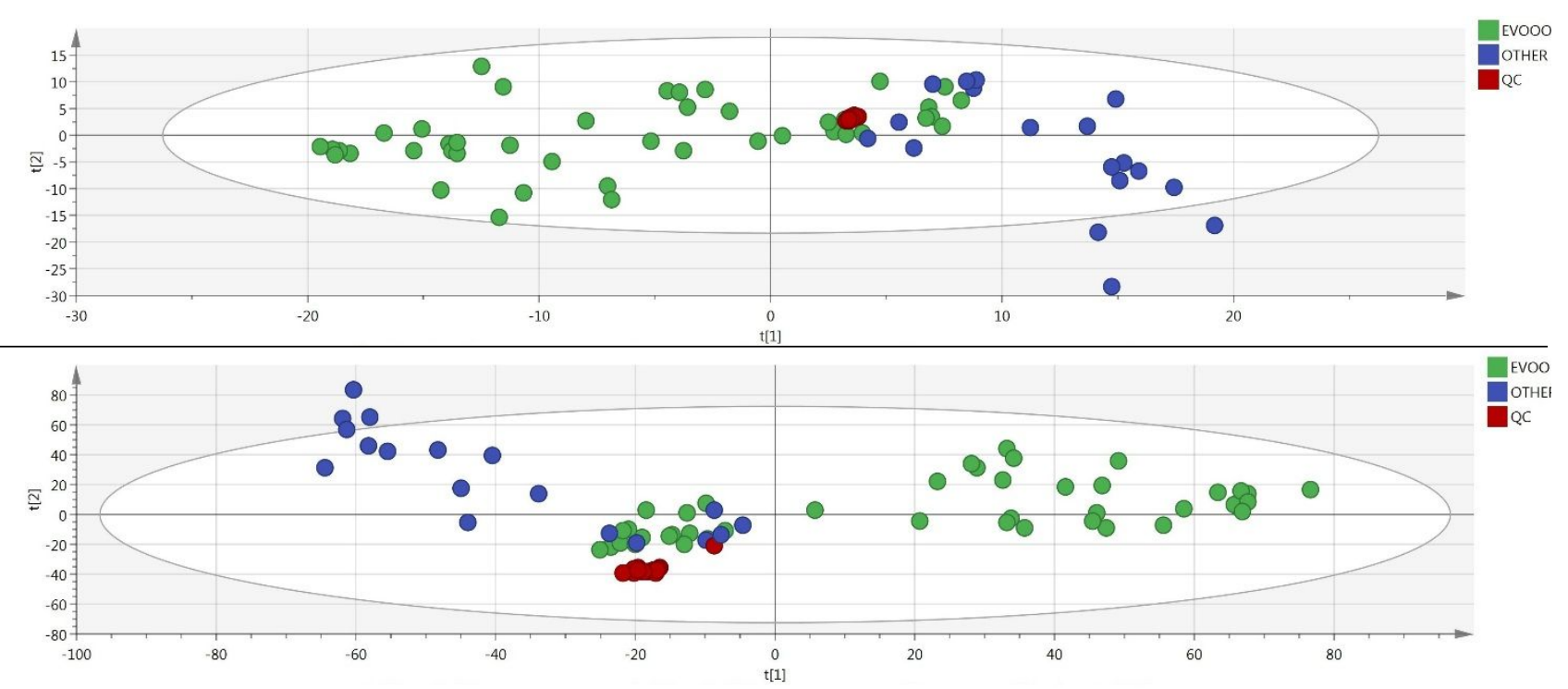

Figure S3. ESI - PCA Scores plots of the samples including QCs (X axis: PC1, Y axis: PC2). A: Laboratory \#1; number of PCs: 14; explained variance of each PC: PC1 32.7\%, PC2 15.9\%, PC3 11.1\%, PC4 6.9\%, PC5 5.9\%, PC6 3.4\%, PC7 2.9\%, PC8 2.4\%, PC9 2.1\%, PC10 1.8\%, PC11 1.3\%, PC12 1.2\%, PC13 1.0\%, PC14 1.0\%.:B: Laboratory \#2; number of PCs: 5; explained variance of each PC: PC1 21.2\%, PC2 9.5\%, PC3 8.2\%, PC4 6.4\%, PC5 5.1\%,. Green dots: "EVOO" samples; blue dots: "OTHER" samples; red dots. "QC" samples. 
The PCA and PLS-DA scores plot of the results obtained with the negative ionization mode are presented in figures S4 and S5.

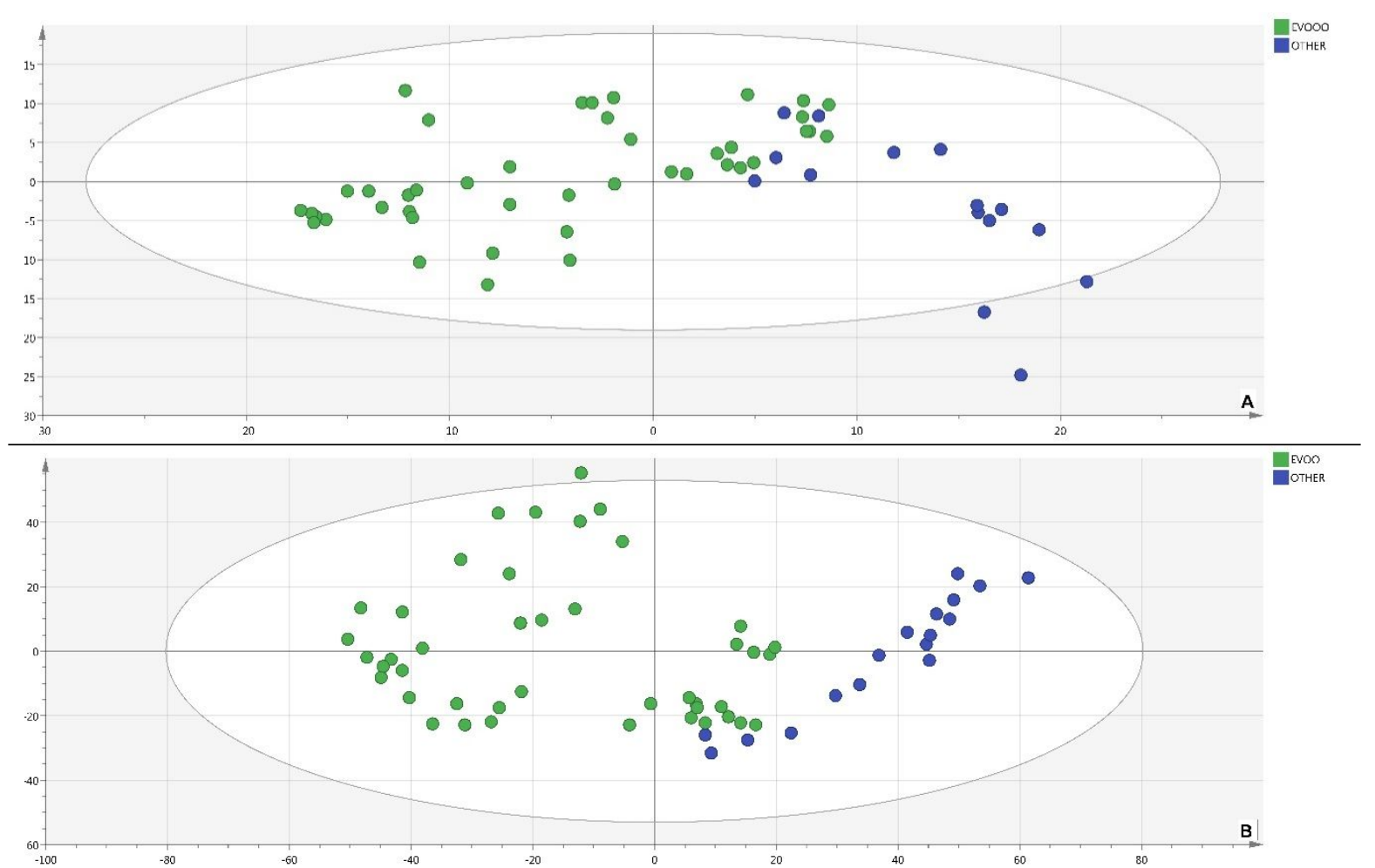

Figure S4. ESI - PCA Scores plots of the samples (X axis: PC1, Y axis: PC2). A: Laboratory \#1; number of PCs: 9; explained variance of each PC: PC1 33.7\%, PC2 15.7\%, PC3 11.3\%, PC4 7.2\%, PC5 5.4\%, PC6 3.6\%, PC7 3.1\%, PC8 2.4\%, PC9 2.1\%. B. Laboratory \#2; number of PCs: 7; explained variance of each PC: PC1 12.0\%, PC2 10.0\%, PC3 9.1\%, PC4 8.5\%, PC5 7.9\%, PC6 7.1\%, PC7 6.4\%. Green dots: “EVOO” samples; blue dots: "OTHER" samples. 


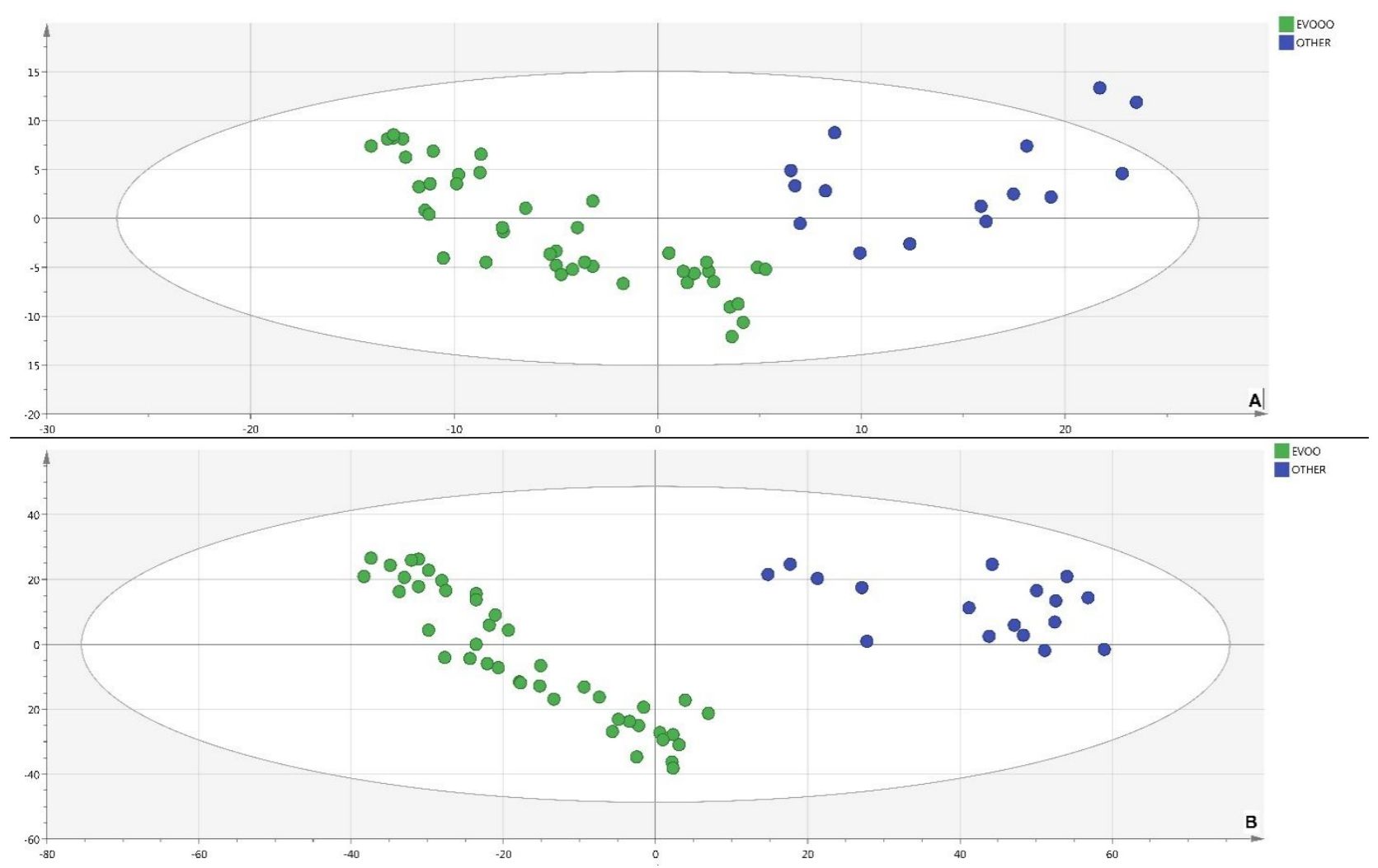

Figure S5. ESI - PLS-DA Scores plots of the samples(X axis: Component $1, Y$ axis: Component 2). $\underline{A}$ :

Laboratory \#1; $R^{2} X($ cum $)=0.682 ; R^{2} Y($ cum $)=0.954 ; Q^{2}($ cum $)=0.871$. B: Laboratory $\# 2 ; R^{2} X($ cum $)=0.235$; $R^{2} Y($ cum $)=0.989 ; Q^{2}$ (cum) = 0.906. Green dots: "EVOO" samples; blue dots: "OTHER" samples. 


\begin{tabular}{|c|c|c|c|c|c|}
\cline { 3 - 6 } \multicolumn{2}{c|}{} & \multicolumn{2}{c|}{ Laboratory \#1 } & \multicolumn{2}{c|}{ Laboratory \#2 } \\
\hline SAMPLE & CLASS & $\begin{array}{c}\text { \% affinity } \\
\text { “EVOO” group }\end{array}$ & $\begin{array}{c}\text { \% affinity } \\
\text { "NOT EVOO” } \\
\text { group }\end{array}$ & $\begin{array}{c}\text { \% affinity } \\
\text { “EVOO” group }\end{array}$ & $\begin{array}{c}\text { \%NOT EVOO” } \\
\text { group }\end{array}$ \\
\hline CP_30 & EVOO & $88 \%$ & $12 \%$ & $91 \%$ & $9 \%$ \\
\hline CP_31 & EVOO & $100 \%$ & $0 \%$ & $92 \%$ & $8 \%$ \\
\hline CP_32 & EVOO & $100 \%$ & $0 \%$ & $98 \%$ & $2 \%$ \\
\hline DEO3 & NOT EVOO & $0 \%$ & $100 \%$ & $22 \%$ & $78 \%$ \\
\hline DEO_DEA2 & NOT EVOO & $0 \%$ & $100 \%$ & $0 \%$ & $100 \%$ \\
\hline MIX_D & NOT EVOO & $3 \%$ & $97 \%$ & $19 \%$ & $81 \%$ \\
\hline
\end{tabular}

Table S1: Predicted group affinity for the samples of the validation set obtained with the ESI+ PLS-DA models. According to the software rules, values higher than $65 \%$ correspond to a certain belonging of the sample to that group

\begin{tabular}{|c|c|c|c|c|c|}
\hline \multirow[b]{2}{*}{ SAMPLE } & \multirow[b]{2}{*}{ CLASS } & \multicolumn{2}{|c|}{ Laboratory \#1 } & \multicolumn{2}{|c|}{ Laboratory \#2 } \\
\hline & & $\begin{array}{c}\text { \% affinity } \\
\text { "EVOO" } \\
\text { group }\end{array}$ & $\begin{array}{c}\text { \% affinity } \\
\text { "NOT EVOO" } \\
\text { group }\end{array}$ & $\begin{array}{c}\text { \% affinity } \\
\text { "EVOO" } \\
\text { group }\end{array}$ & $\begin{array}{c}\text { \% affinity } \\
\text { "NOT EVOO" } \\
\text { group }\end{array}$ \\
\hline CP_30 & EVOO & $100 \%$ & $0 \%$ & $96 \%$ & $4 \%$ \\
\hline CP_31 & EVOO & $100 \%$ & $0 \%$ & $100 \%$ & $0 \%$ \\
\hline CP_32 & EVOO & $100 \%$ & $0 \%$ & $100 \%$ & $0 \%$ \\
\hline DEO3 & NOT EVOO & $0 \%$ & $100 \%$ & $0 \%$ & $100 \%$ \\
\hline DEO_DEA2 & NOT EVOO & $14 \%$ & $86 \%$ & $0 \%$ & $100 \%$ \\
\hline MIX_D & NOT EVOO & $12 \%$ & $88 \%$ & $0 \%$ & $66 \%$ \\
\hline
\end{tabular}

Table S2: Predicted group affinity for the samples of the validation set obtained with the ESI- PLS-DA models. According to the software rules, values higher than $65 \%$ correspond to a certain belonging of the sample to that group 


\section{SECTION 2 - COMPOUND IDENTIFICATION}

The complete list of the supposed names of the 12 selected compounds is presented in Table S3, together with their identification level [1] and their mean area values in the different groups. The "Variables trends plot" of "Compound 1" and of "Compound 7" are presented in figure S6.

\begin{tabular}{|c|c|c|c|c|}
\hline $\begin{array}{l}\text { Compound } \\
\text { ID }\end{array}$ & Name & $\begin{array}{l}\text { ID } \\
\text { Level }\end{array}$ & Lab\#1 Area values & Lab\#2 Area values \\
\hline 1 & $\begin{array}{c}\text { Propylene glycol - } 1 \\
\text { Stearate }\end{array}$ & 3 & 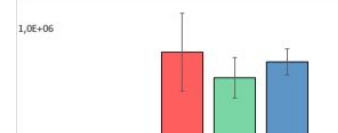 & so.ess \\
\hline 2 & 4-Phenylbutyric acid & 2 & & N.D. \\
\hline 3 & Tyrosine ethyl ester & 3 & & N.D. \\
\hline 4 & Geranic Acid & 3 & & N.D. \\
\hline 5 & $\begin{array}{c}3,4,5- \\
\text { trimethoxydihydrocinnamic } \\
\text { acid }\end{array}$ & 3 & 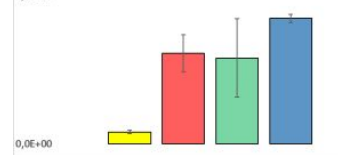 & N.D. \\
\hline 6 & $\begin{array}{l}\text { Propyl-12-hydroxy-9- } \\
\text { octadecenoate }\end{array}$ & 3 & & N.D. \\
\hline 7 & N.A. & 4 & & \\
\hline 8 & N.A. & 4 & & \\
\hline 9 & $\begin{array}{c}\text { (2R,3E)-5-(3-Chloro-5-formyl-2,6- } \\
\text { dihydroxy-4-methylphenyl)-3- } \\
\text { methyl-1-[(1S,2R,6R)-1,2,6- } \\
\text { trimethyl-3-oxocyclohexyl]-3- } \\
\text { penten-2-yl acetate }\end{array}$ & 2 & $\underbrace{1,4 \in+005}_{0,0 \in+00}$ & $-{ }^{-1}$ \\
\hline 10 & N.A. & 4 & ${ }_{0,0,0+\infty} \quad-\square$ & \\
\hline
\end{tabular}




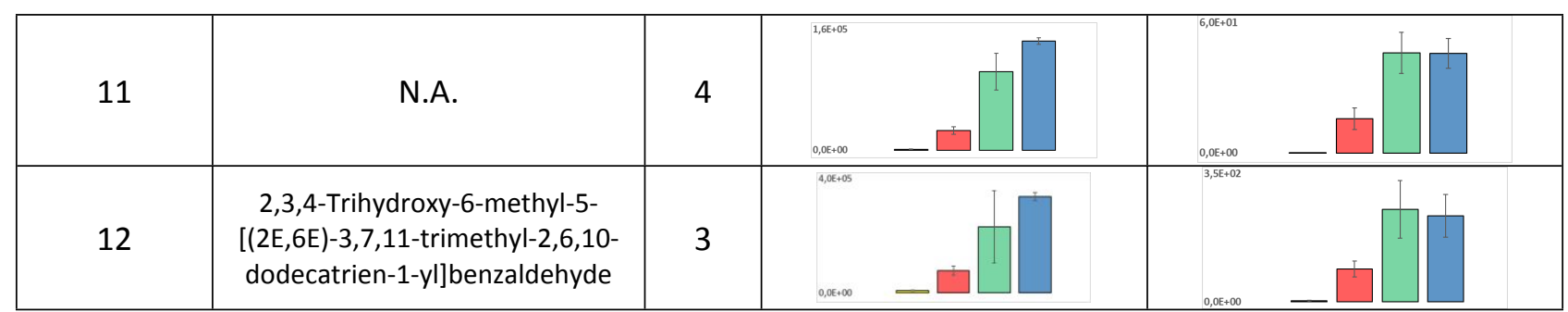

Table S3: compounds description and comparison of their mean area values (+/- standard error) through the groups (yellow bar: EVOO; red bar: DEO; green bar: DEA, blue bar: DEO+DEA samples) N.A.= Not available

\section{COMPOUND 1}

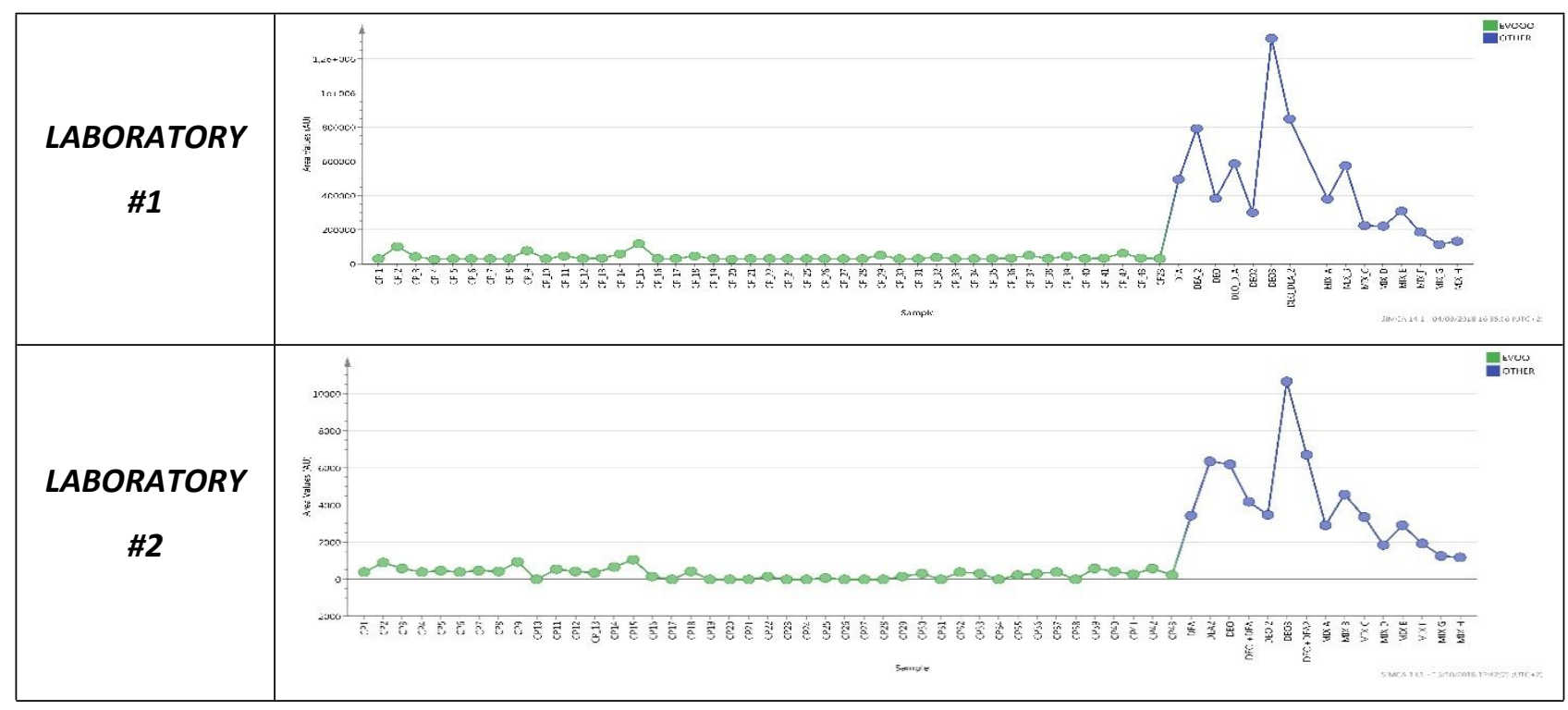

COMPOUND 7

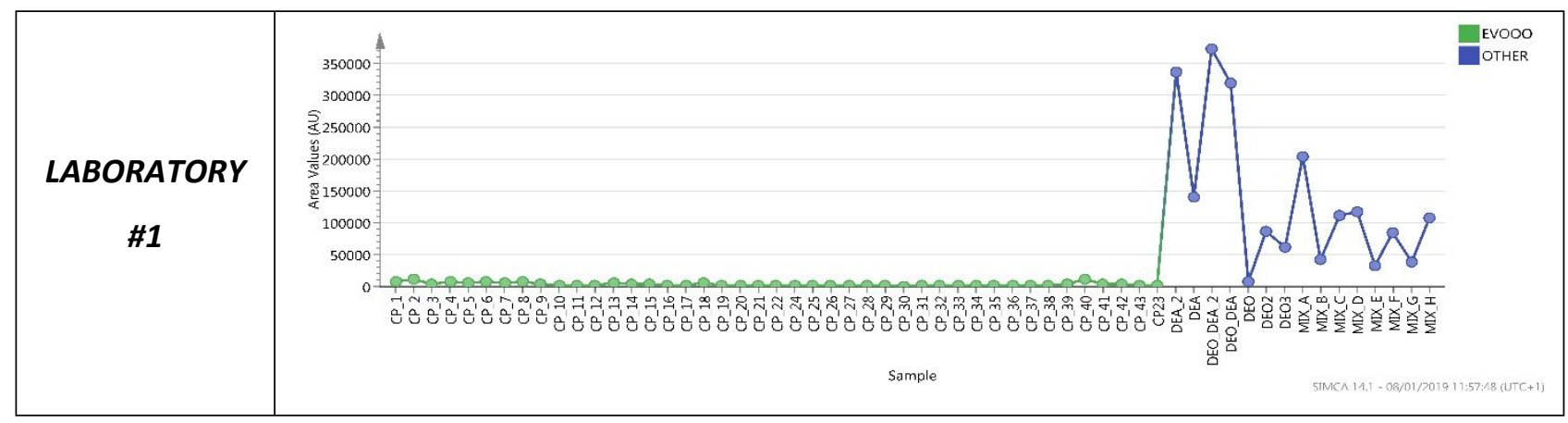




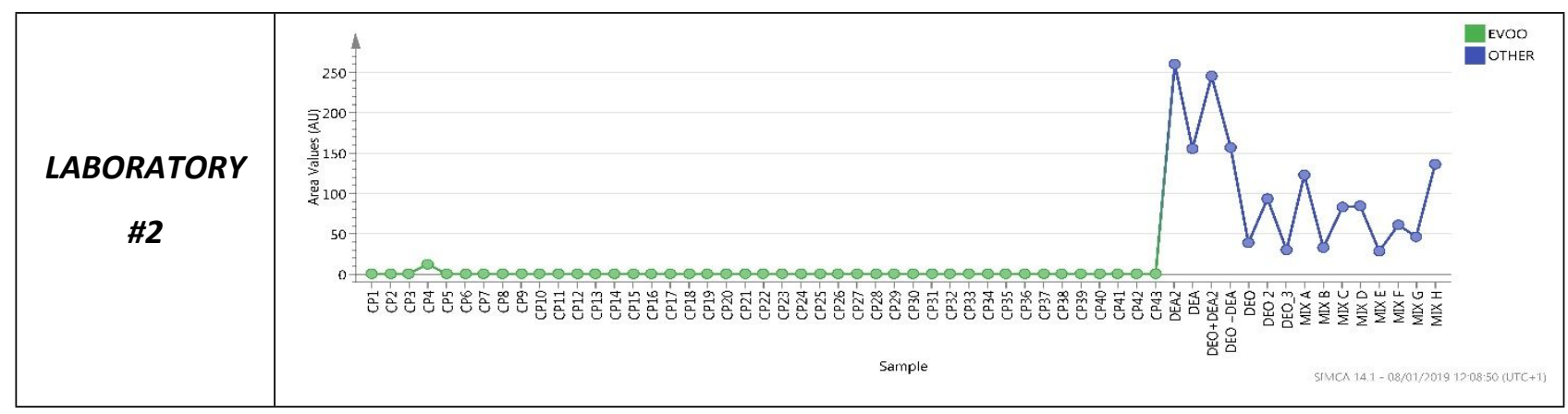

Figure S6. Variable trend plots of "Compound 1" and of "Compound 7". Green dots: area values of the marker in "EVOO" group; blue dots: area values of the marker in "OTHER" group.

\section{SECTION 3 - EVALUATION OF THE INTER-LABORATORY STUDY}

The comparison of the MS/MS spectra of the compounds selectedwith the two instrument is presented in the following figures

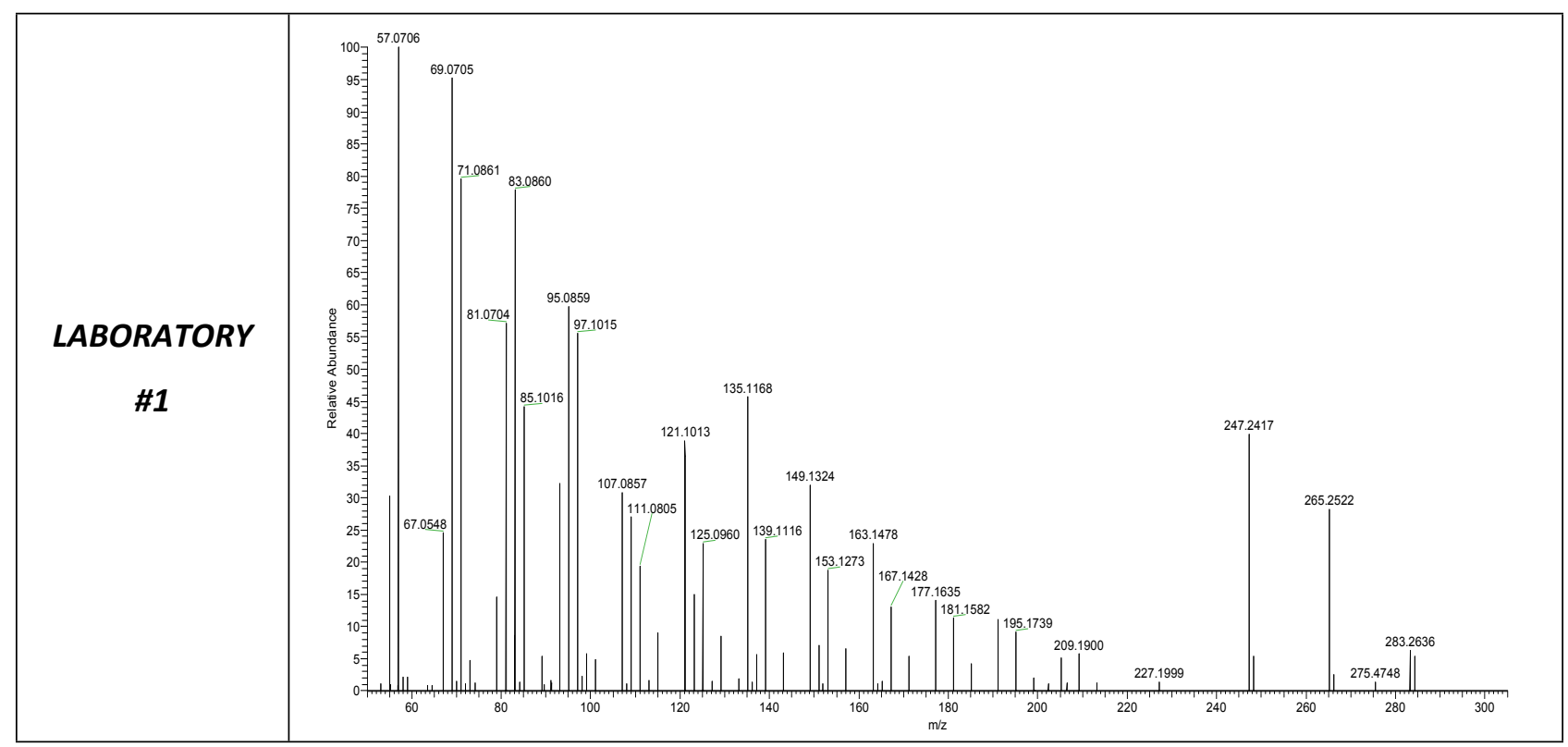




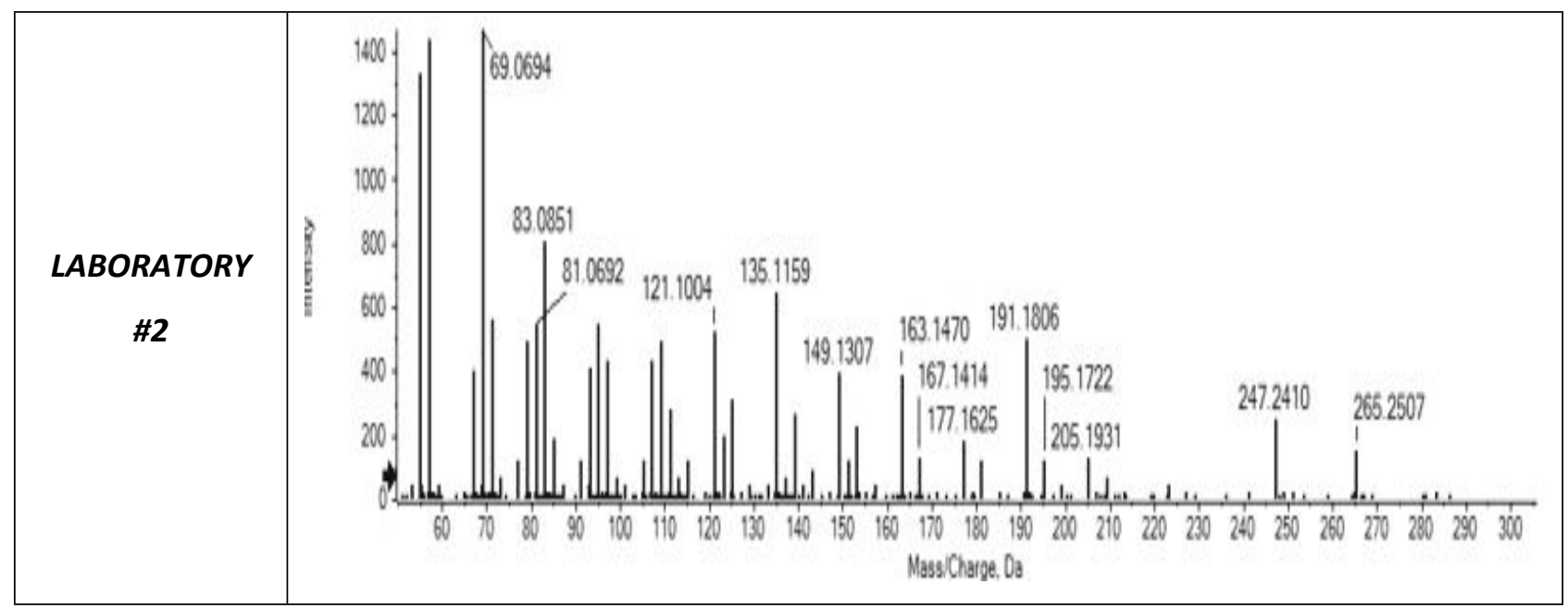

Figure S7 Comparison of the MS/MS spectra of the "Compound 1" obtained in Laboratory \#1 and in Laboratory \#2. Instrumental conditions are detailed in the text

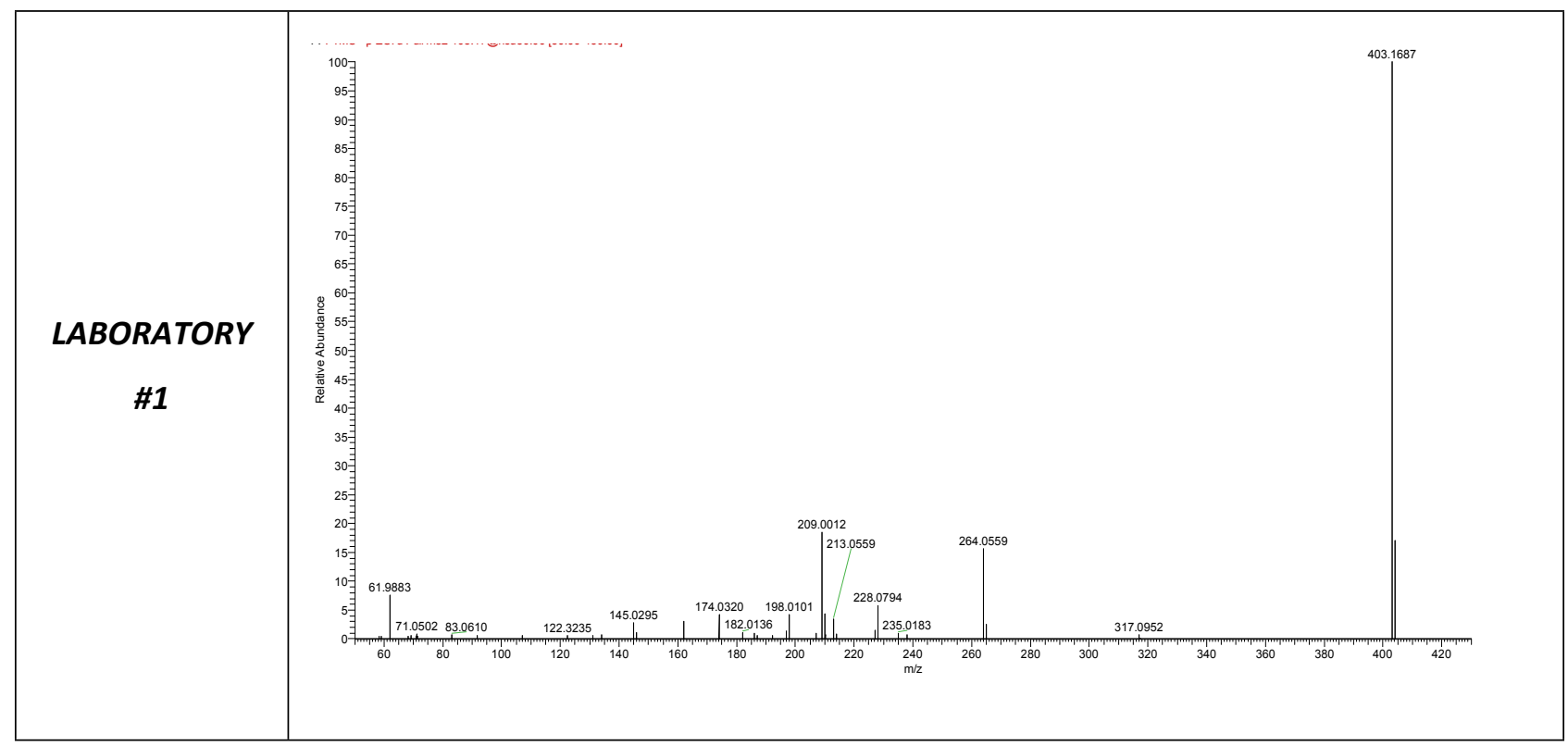




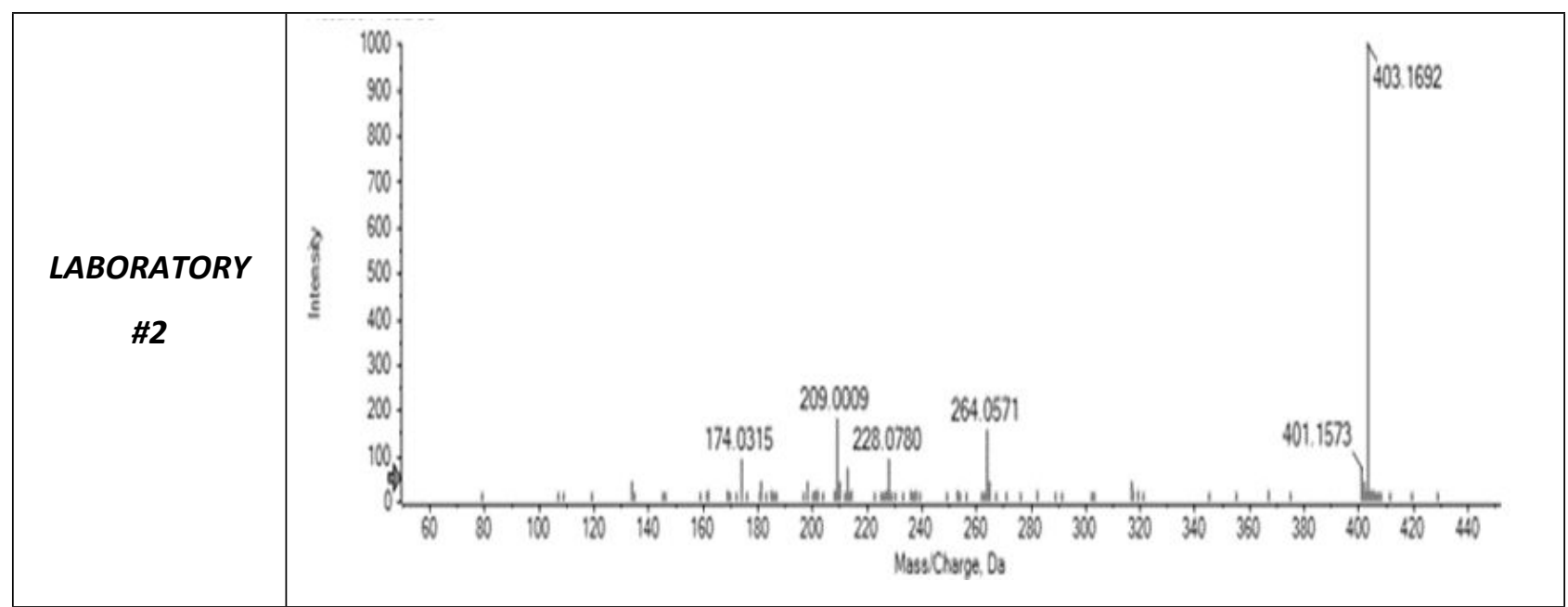

Figure S8 Comparison of the MS/MS spectra of the "Compound 7" obtained in Laboratory \#1 and in Laboratory \#2. Instrumental conditions are detailed in the text 


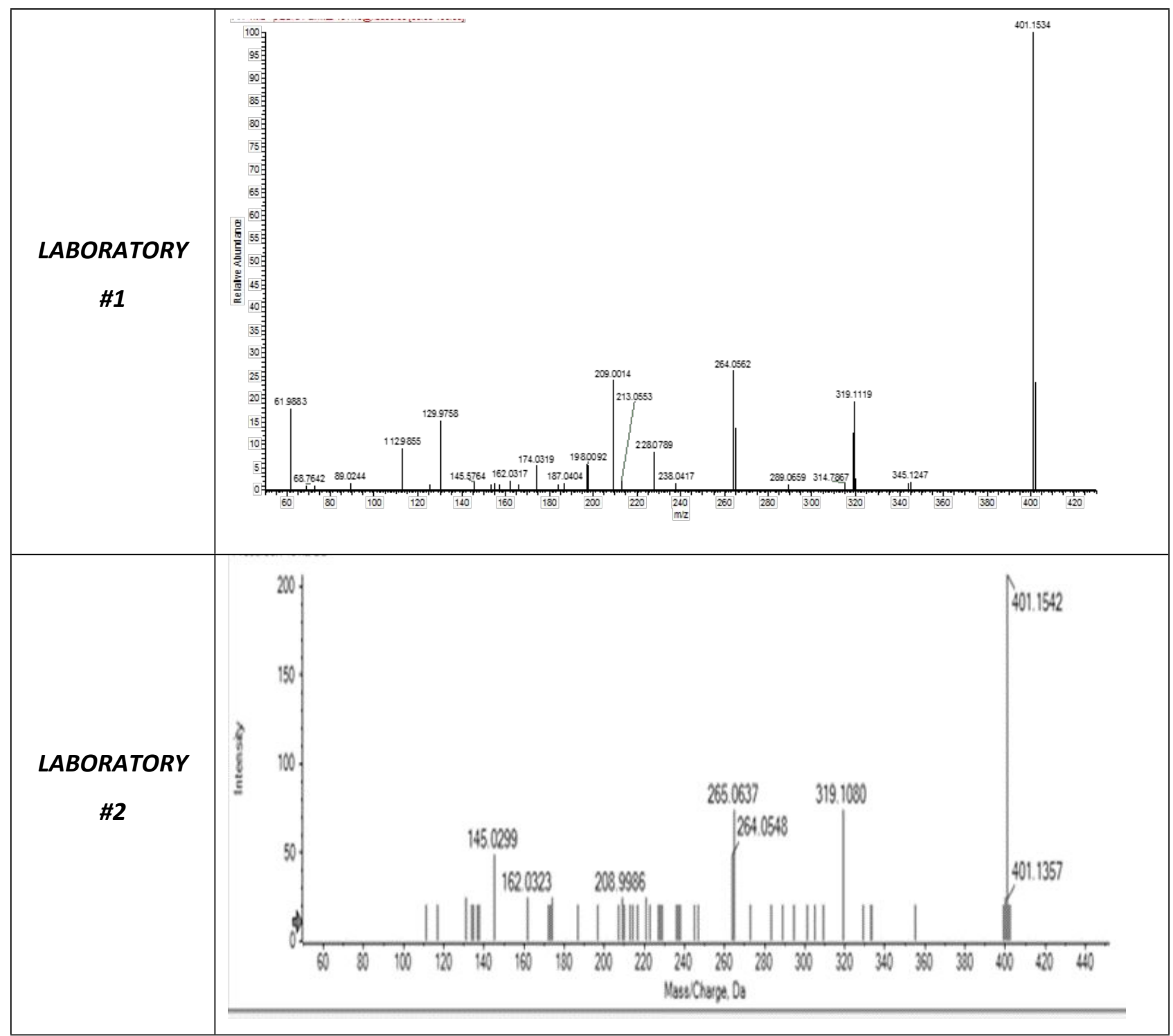

Figure S9 Comparison of the MS/MS spectra of the "Compound 8" obtained in Laboratory \#1 and in Laboratory \#2. Instrumental conditions are detailed in the text 


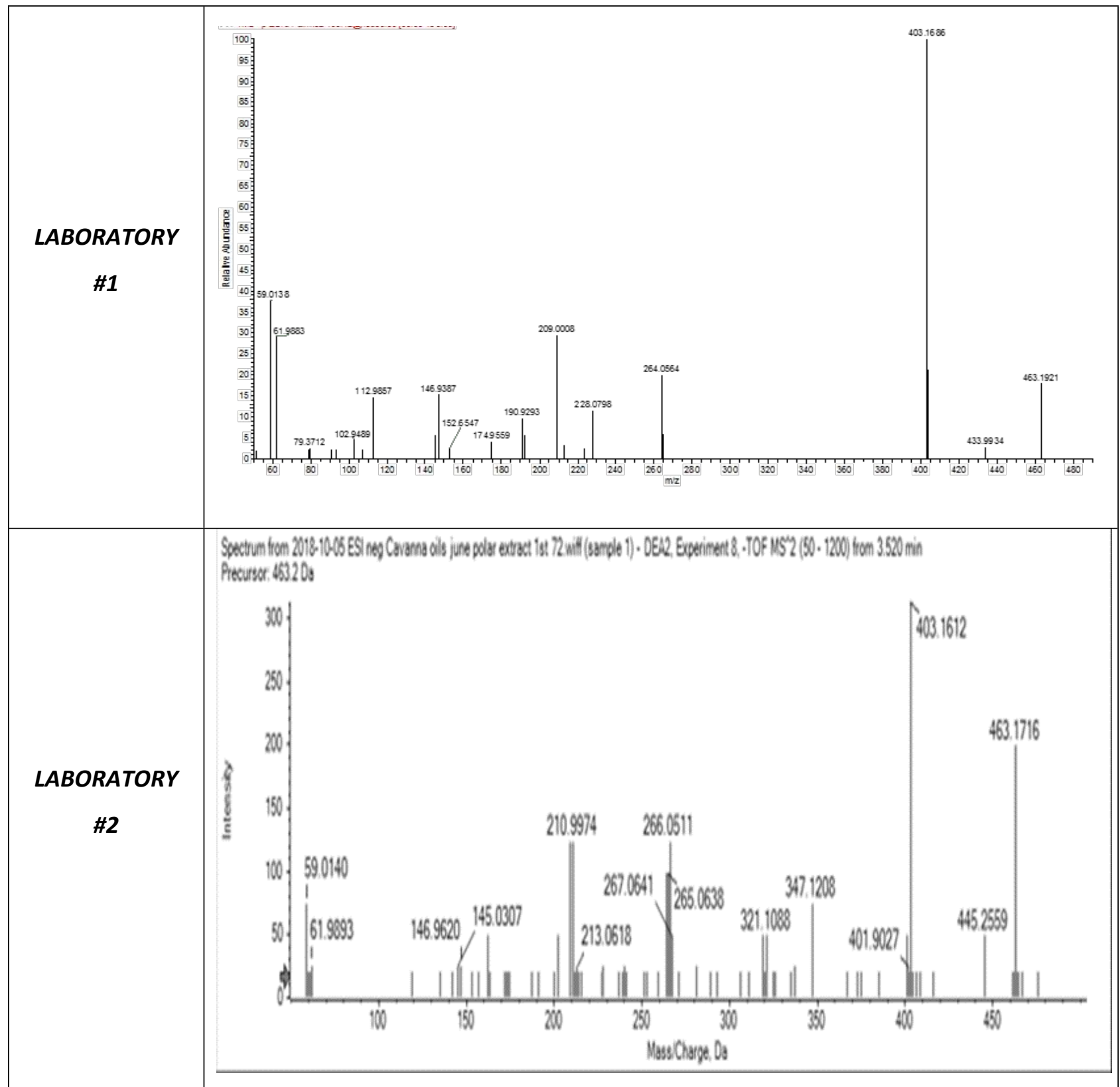

Figure S10 Comparison of the MS/MS spectra of the "Compound 9" obtained in Laboratory \#1 and in Laboratory \#2. Instrumental conditions are detailed in the text 


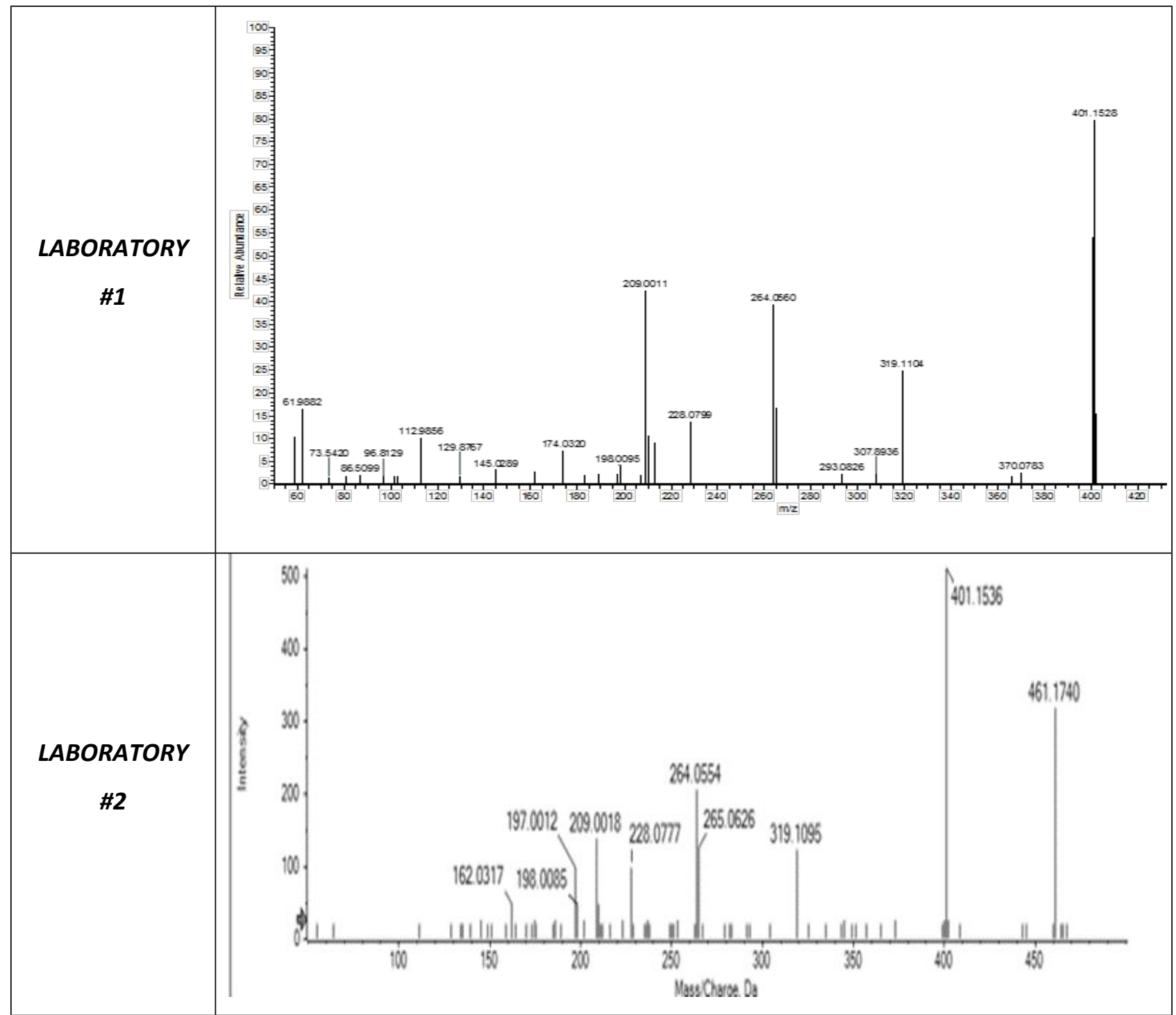

Figure S11 Comparison of the MS/MS spectra of the "Compound 10" obtained in Laboratory \#1 and in Laboratory \#2. Instrumental conditions are detailed in the text 


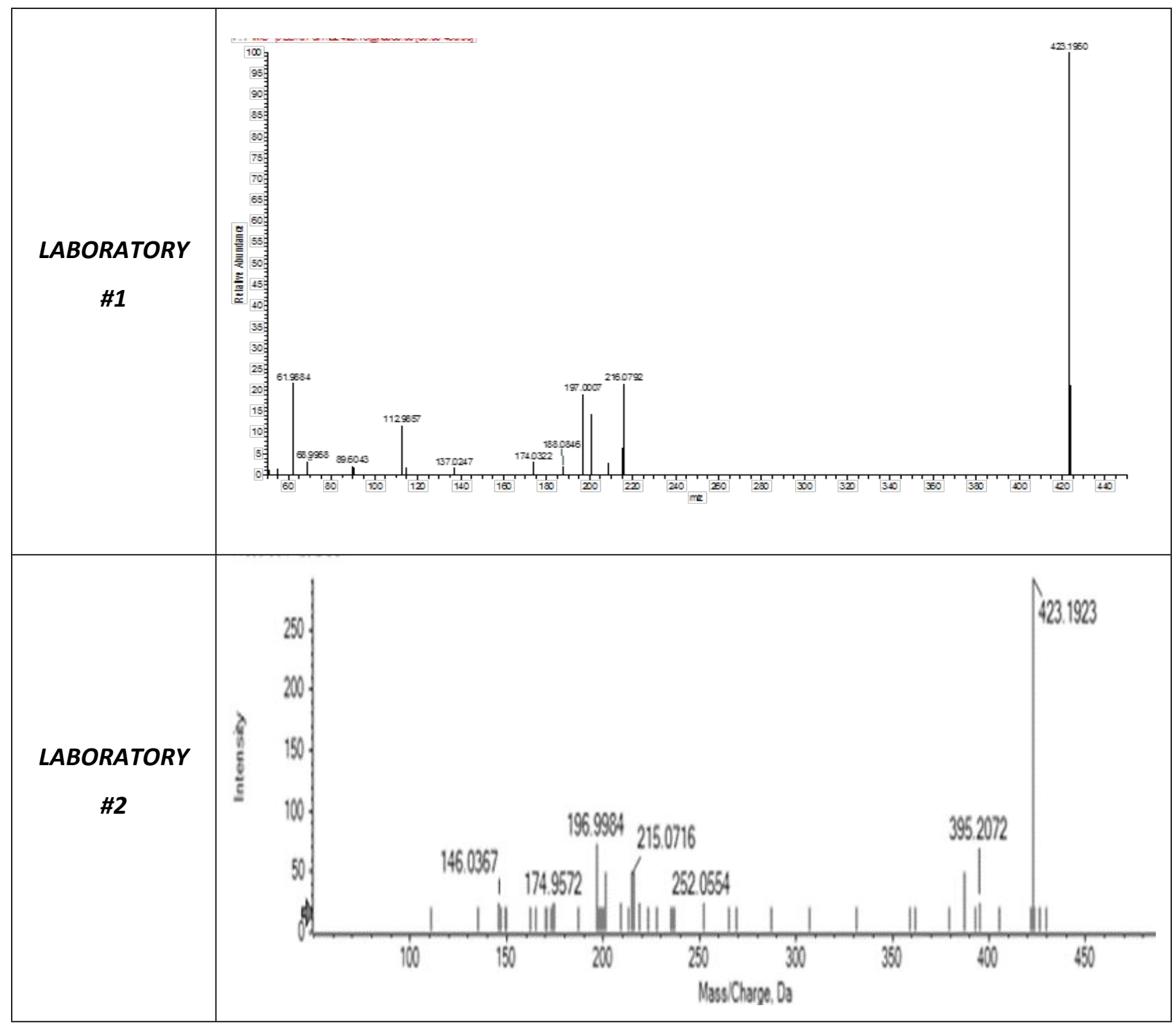

Figure S12 Comparison of the MS/MS spectra of the "Compound 11" obtained in Laboratory\#1 and in Laboratory \#2. Instrumental conditions are detailed in the text 


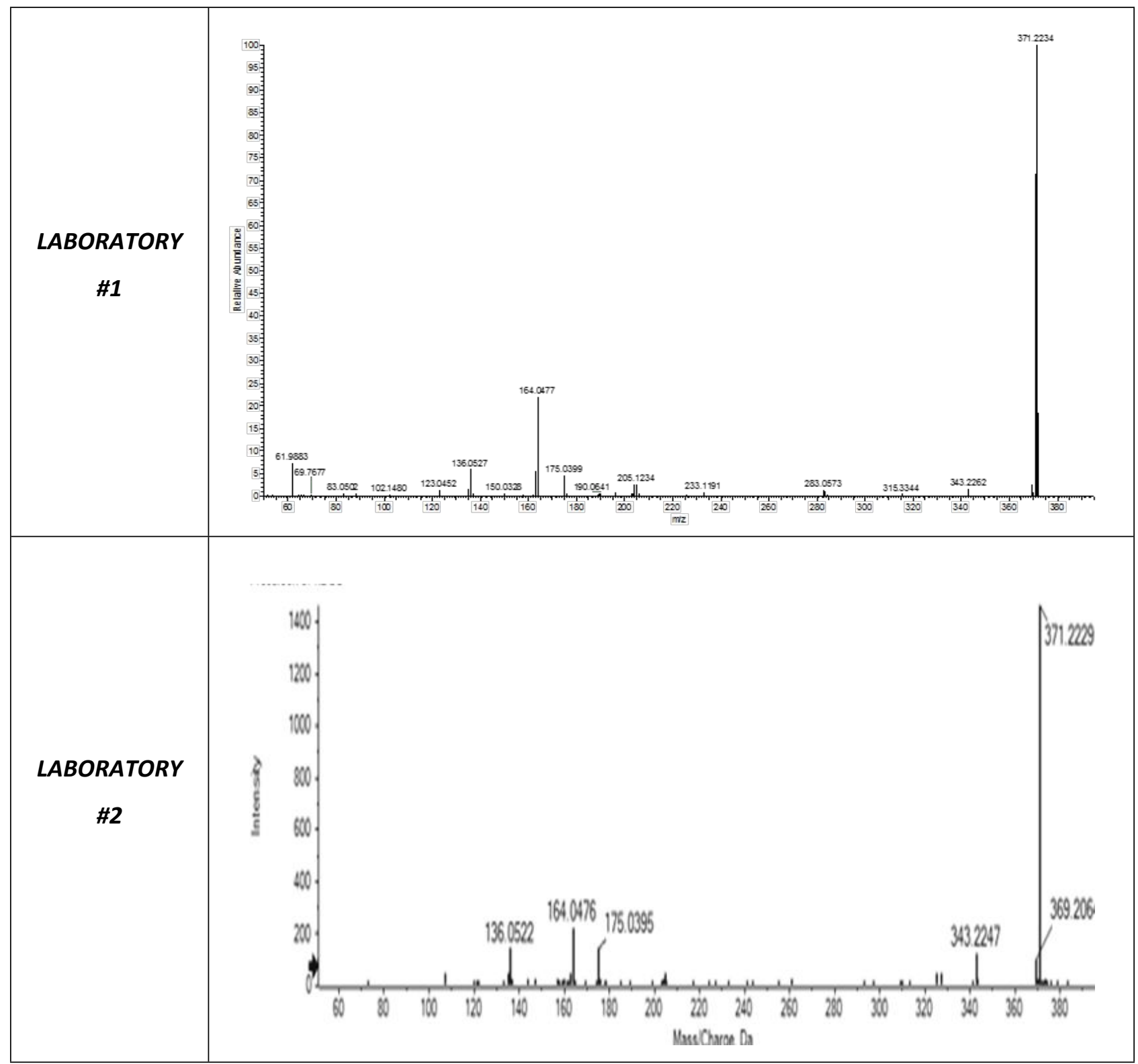

Figure S13 Comparison of the MS/MS spectra of the "Compound 12" obtained in Laboratory \#1 and in Laboratory \#2. Instrumental conditions are detailed in the text 
The global list of the samples used in this study is detailed in table S4.

\begin{tabular}{|c|c|c|c|c|}
\hline NAME & TYPE & YEAR & SUPPLIER & STORAGE \\
\hline CP_1 & EVOO & $2015 / 2016$ & 1 & $2-8^{\circ} \mathrm{C}$ \\
\hline CP_2 & EVOO & $2015 / 2016$ & 1 & $2-8^{\circ} \mathrm{C}$ \\
\hline CP_3 & EVOO & $2015 / 2016$ & 2 & $2-8^{\circ} \mathrm{C}$ \\
\hline CP_4 & EVOO & $2015 / 2016$ & 2 & $2-8^{\circ} \mathrm{C}$ \\
\hline CP_5 & EVOO & $2015 / 2016$ & 2 & $2-8^{\circ} \mathrm{C}$ \\
\hline CP_6 & EVOO & $2015 / 2016$ & 2 & $2-8^{\circ} \mathrm{C}$ \\
\hline CP_7 & EVOO & $2015 / 2016$ & 2 & $2-8^{\circ} \mathrm{C}$ \\
\hline CP_8 & EVOO & $2015 / 2016$ & 2 & $2-8^{\circ} \mathrm{C}$ \\
\hline CP_9 & EVOO & $2015 / 2016$ & 1 & $2-8^{\circ} \mathrm{C}$ \\
\hline CP_10 & EVOO & $2015 / 2016$ & 3 & $2-8^{\circ} \mathrm{C}$ \\
\hline CP_11 & EVOO & $2015 / 2016$ & 3 & $2-8^{\circ} \mathrm{C}$ \\
\hline CP_12 & EVOO & $2015 / 2016$ & 3 & $2-8^{\circ} \mathrm{C}$ \\
\hline CP_13 & EVOO & $2016 / 2017$ & 2 & $2-8^{\circ} \mathrm{C}$ \\
\hline CP_14 & EVOO & $2016 / 2017$ & 2 & $2-8^{\circ} \mathrm{C}$ \\
\hline CP_15 & EVOO & $2016 / 2017$ & 2 & $2-8^{\circ} \mathrm{C}$ \\
\hline CP_16 & EVOO & $2016 / 2017$ & 2 & $2-8^{\circ} \mathrm{C}$ \\
\hline CP_17 & EVOO & $2016 / 2017$ & 2 & $2-8^{\circ} \mathrm{C}$ \\
\hline CP_18 & EVOO & $2016 / 2017$ & 2 & $2-8^{\circ} \mathrm{C}$ \\
\hline CP_19 & EVOO & $2016 / 2017$ & 2 & $2-8^{\circ} \mathrm{C}$ \\
\hline CP_20 & EVOO & $2017 / 2018$ & 2 & $2-8^{\circ} \mathrm{C}$ \\
\hline CP_21 & EVOO & $2017 / 2018$ & 2 & $2-8^{\circ} \mathrm{C}$ \\
\hline CP_22 & EVOO & $2017 / 2018$ & 2 & $2-8^{\circ} \mathrm{C}$ \\
\hline CP_23 & EVOO & $2017 / 2018$ & 2 & $2-8^{\circ} \mathrm{C}$ \\
\hline CP_24 & EVOO & $2017 / 2018$ & 2 & $2-8^{\circ} \mathrm{C}$ \\
\hline CP_25 & EVOO & $2017 / 2018$ & 2 & $2-8^{\circ} \mathrm{C}$ \\
\hline CP_26 & EVOO & $2017 / 2018$ & 2 & $2-8^{\circ} \mathrm{C}$ \\
\hline CP_27 & EVOO & $2017 / 2018$ & 2 & $2-8^{\circ} \mathrm{C}$ \\
\hline CP_28 & EVOO & $2017 / 2018$ & 2 & $2-8^{\circ} \mathrm{C}$ \\
\hline CP_29 & EVOO & $2017 / 2018$ & 2 & $2-8^{\circ} \mathrm{C}$ \\
\hline CP_30 & EVOO & $2017 / 2018$ & 2 & $2-8^{\circ} \mathrm{C}$ \\
\hline CP_31 & EVOO & $2017 / 2018$ & 2 & $2-8^{\circ} \mathrm{C}$ \\
\hline CP_32 & EVOO & $2016 / 2017$ & 2 & $2-8^{\circ} \mathrm{C}$ \\
\hline CP_33 & EVOO & $2015 / 2016$ & 2 & $2-8^{\circ} \mathrm{C}$ \\
\hline CP_34 & EVOO & $2017 / 2018$ & 2 & $2-8^{\circ} \mathrm{C}$ \\
\hline CP_35 & EVOO & $2017 / 2018$ & 2 & $2-8^{\circ} \mathrm{C}$ \\
\hline CP_36 & EVOO & $2017 / 2018$ & 2 & $2-8^{\circ} \mathrm{C}$ \\
\hline CP_37 & EVOO & $2017 / 2018$ & 2 & $2-8^{\circ} \mathrm{C}$ \\
\hline CP_38 & EVOO & $2017 / 2018$ & 2 & $2-8^{\circ} \mathrm{C}$ \\
\hline CP_39 & EVOO & $2015 / 2016$ & 1 & Room Temperature \\
\hline CP_40 & EVOO & $2015 / 2016$ & 1 & Room Temperature \\
\hline CP_41 & EVOO & $2015 / 2016$ & 1 & Room Temperature \\
\hline
\end{tabular}




\begin{tabular}{|c|c|c|c|c|}
\hline NAME & TYPE & YEAR & SUPPLIER & STORAGE \\
\hline CP_42 & EVOO & $2015 / 2016$ & 1 & Room Temperature \\
\hline CP_43 & EVOO & $2015 / 2016$ & 1 & Room Temperature \\
\hline DEO & DEODORIZED & $/$ & $/$ & $2-8^{\circ} \mathrm{C}$ \\
\hline DEO2 & DEODORIZED & $/$ & $/$ & $2-8^{\circ} \mathrm{C}$ \\
\hline DEO3 & DEODORIZED & $/$ & $/$ & $2-8^{\circ} \mathrm{C}$ \\
\hline DEA & DEACIDIFIED & $/$ & $/$ & $2-8^{\circ} \mathrm{C}$ \\
\hline DEA2 & DEACIDIFIED & $/$ & $/$ & $2-8^{\circ} \mathrm{C}$ \\
\hline DEO_DEA & DEODORIZED AND DEACIDIFIED & $/$ & $/$ & $2-8^{\circ} \mathrm{C}$ \\
\hline DEO_DEA2 & DEODORIZED AND DEACIDIFIED & $/$ & $/$ & $2-8^{\circ} \mathrm{C}$ \\
\hline MIX A & EVOO 25\% + DEA-DEO 75\% & $/$ & $/$ & $2-8^{\circ} \mathrm{C}$ \\
\hline MIX B & EVOO 25\% + DEO 75\% & $/$ & $/$ & $2-8^{\circ} \mathrm{C}$ \\
\hline MIX C & EVOO 55\% + DEA-DEO 45\% & $/$ & $/$ & $2-8^{\circ} \mathrm{C}$ \\
\hline MIX D & EVOO 60\%+ DEA-DEO 40\% & $/$ & $/$ & $2-8^{\circ} \mathrm{C}$ \\
\hline MIXE & EVOO 50\% + DEO 50\% & $/$ & $/$ & $2-8^{\circ} \mathrm{C}$ \\
\hline MIX F & EVOO 40\% + DEO 60\% & $/$ & $/$ & $2-8^{\circ} \mathrm{C}$ \\
\hline MIX G & Commercial DEO sample & $/$ & $/$ & $2-8^{\circ} \mathrm{C}$ \\
\hline MIX H & Commercial DEO sample & $/$ & $/$ & $2-8^{\circ} \mathrm{C}$ \\
\hline
\end{tabular}

Table S4: list and description of the samples. CP_19, CP_26 and CP_31 were produced with olives coming from European Union

\section{REFERENCES}

[1] Schymanski, E.; Jeon, J.; Gulde, R.; Fenner, K.; Ruff, M.; Singer, H.; Hollender, J. Identifying Small Molecules via High Resolution Mass Spectrometry: Communicating Confidence. Environ. Sci. Technol. 2014, 48, 2097-2098. 